\title{
Genomic screening of testicular germ cell tumors from monozygotic twins
}

Sara Martoreli Silveira ${ }^{1 \dagger}$, Isabela Werneck da Cunha ${ }^{2 \dagger}$, Fabio Albuquerque Marchi ${ }^{3}$, Ariane Fidelis Busso ${ }^{1}$, Ademar Lopes ${ }^{4}$ and Silvia Regina Rogatto ${ }^{1,5^{*}}$

\begin{abstract}
Background: Testicular germ cell tumors (TGCTs) account for 1-2\% of all tumors in young and middle aged men. A 75-fold increase in TCGT development has been reported for monozygotic (MZ) twins. Therefore, the occurrence of simultaneous tumors in $\mathrm{MZ}$ twins emphasizes the importance of genetic factors that influence the risk of developing these tumors. Genomic screening was performed for one family containing MZ twins with testicular germ cell tumors, in order to define alterations associated with risk of tumor development.
\end{abstract}

Methods: Copy number alterations were evaluated using array-CGH (4x44K, Agilent Technologies) in one seminoma and one embryonal carcinoma (EC) from MZ twins. In addition, genomic alterations from the tumors and peripheral blood cells of the twins were compared to the parental genomes via their peripheral blood cells.

Results: Embryonal carcinoma (Twin-1 t) presented a lower frequency of genomic alterations compared to the seminoma (Twin-2 t). One minimal common region of loss was observed in 9p13.1-p12 in the comparison between DNA from blood samples for Twin-1 and Twin-2. In this region is mapped the CNTNAP3 gene which was confirmed as involved in losses by qPCR. Comparative analysis of novel CNVs between the Twin- $1 \mathrm{t}$ and Twin- $2 \mathrm{t}$ showed five minimal common regions involving gain at chromosomes 12 (12p12.3-p11.1 and 12p13.33-p12.3), while losses were observed at 10p15.3-p15.2, 13q21.1-q21.2 and 15q11.1-q11.2. In addition, one exclusive rare copy number alteration was detected in Twin-1 t and Twin-2 t, and 19 novel alterations were identified in the Twin-2 $\mathrm{t}$.

Conclusion: Distinct genomic profiles for MZ twins with phenotypically different TGCT were described. Of particular interest, $12 p$ gains were detected exclusively in tumor samples. In peripheral blood samples, loss of 9p13.1-p12 was the unique novel CNV shared by the twins, confirming the involvement of CNTNAP3 gene in TGCTs development. Although similar CNV profiles were shared by both the peripheral blood and tumor samples of the twins, tumor-specific CNV loci were identified for seminoma and non-seminomatous tumors. These findings suggest the presence of de novo germline structural alterations and TGCT predisposition.

Keywords: Testicular germ cell tumors, Seminomas, Embryonal carcinoma, Array-based comparative genomic hybridization, Molecular markers, Genomic imbalances, Copy number variations

\section{Background}

Testicular tumors are relatively uncommon, accounting for $1-2 \%$ of all tumors in males. Testicular germ cell tumors (TGCTs) represent $95 \%$ of testicular cancers and are histologically classified as seminoma or non-seminoma [1]. Seminoma presents a homogenous histological pattern

\footnotetext{
*Correspondence: silvia.rogatto@cipe.accamargo.org.br

${ }^{\dagger}$ Equal contributors

'Neogene Laboratory, CIPE, A. C. Camargo Cancer Center, São Paulo, Brazil ${ }^{5}$ Department of Urology, Faculty of Medicine, UNESP, Botucatu, São Paulo, Brazil

Full list of author information is available at the end of the article
}

that resembles primordial germ cells (PGCs) [2]. Nonseminomatous tumors are classified as embryonic (teratoma) and extra-embryonic (yolk sac and choriocarcinoma) according to their pattern of cell differentiation, or as embryonal cell carcinomas when originating from undifferentiated cells [3,4]. It is important to highlight that non-seminomatous mixed germ cell tumors display a more aggressive clinical behavior, frequently developing local recurrence and distant metastasis [5].

The presence of these tumors in monozygotic (MZ) twins is extremely rare and therefore, it is difficult to 
assess the impact and risk associated with inheritance. Monozygotic and dizygotic twins present a 75 and 35-fold increased risk of developing TCGT, respectively [6]. In a meta-analysis of testicular cancer in twins, two of seven studies demonstrated a significantly increased risk of testicular cancer among twins [7]. Therefore, a simultaneous occurrence of tumors in MZ twins stresses the importance of a genetic factor, which influences their risk of development.

The etiology of testicular cancer is not completely understood, however, a number of risk factors have been described in the literature, including cryptorchidism, a family history of testicular cancer, testicular atrophy, testicular microlithiasis, infertility, HIV infection and imbalance of estrogen and androgen levels in twin pregnancies [8-11]. In addition, rare inherited diseases, such as Down's syndrome, Klinefelter's syndrome, and XY dysgenesis, are associated with an increased risk for testicular cancer [12]. Gains at Xq27, XRCC1 polymorphisms and deletions of the $Y$ chromosome have been described as associated with susceptibility to testicular germ cell tumor [13-17]. Recent genome-wide association studies (GWAS) have identified 29 SNPs mapped at 18 TGCT predisposition loci [18-22]. Several genes have been described as associated with TGCT susceptibility including TERT, SPRY4, BAK1, DMRT1, ATF7IP and KITLG.

In the present study, a genomic screening approach was performed for a pair of 26-year old male MZ twins with embryonal carcinoma and testicular seminoma. Copy number variations (CNV) analyses were presented and discussed with reference to the parental genome, which allowed for the assessment of genomic alterations and respective harbored genes involved in the development of the testicular germ cell tumors.

\section{Methods}

\section{Case description}

A pair of male MZ twins with a diagnosis of TGCTs was admitted to the Sarcoma's Nucleus of the A. C. Camargo Cancer Center, São Paulo, Brazil. Array-CGH analysis was successfully performed for the primary tumors (embryonal carcinoma and seminoma) and the peripheral blood samples from the twins and their parents. Neither patient had received chemotherapy or radiotherapy prior to sample collection. Furthermore, neither twin presented risk factors associated with TCGT as described in the literature (cryptorchidism, familial testicular cancer history, testicular atrophy, testicular microlithiasis, infertility, HIV infection and alterations of estrogen and androgen levels during pregnancy). All family members were advised of the procedures and provided written informed consent. The Human Research Ethics Committee of the Institution approved the study (Protocol EC 21/2014).

Twin-1 was submitted to a right orchiectomy after presenting with a palpable tumor in the right testicle at 21 years of age. Histopathological analysis revealed a mixed germ cell tumor (pT2NxMx) containing both embryonal carcinoma (95\%) and mature teratoma (5\%) components (Figure 1A-B). Immunohistochemistry for the embryonal carcinoma was positive for CD30 and negative for PLAP, HCG and alpha- fetoprotein. Despite the presence of lymphatic and venous invasion, the adjacent testicular anatomy (tunica albuginea and vaginalis) was not compromised and no invasion of the spermatic cord was observed. The surgical margins were negative for the presence of tumor cells. Due to the presence of pulmonary metastases, the patient underwent a three-day regimen of adjuvant chemotherapy with bleomycin, etoposide and cisplatin $(\mathrm{BEP})$, with a complete response. Three years after the

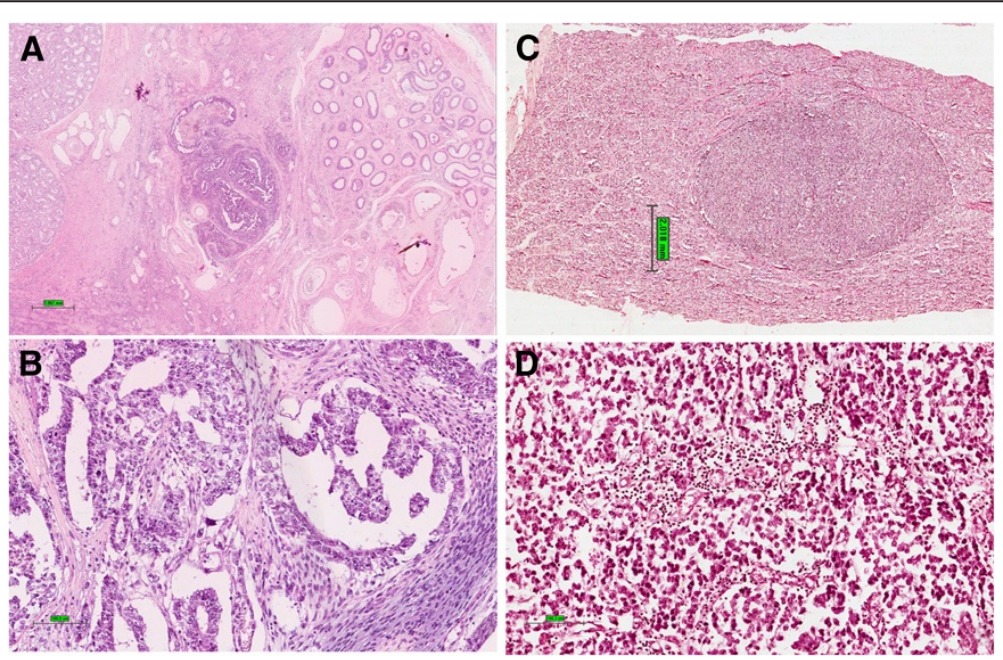

Figure 1 Identical twins diagnosed with different subtypes of testicular germ cell tumors. A) Embryonal carcinoma. B) Embryonal carcinoma in detail, showing a papillary growth pattern. C) Seminoma nodule within the testis D) Seminoma in detail, showing large round cells with lymphocytes. 
initial diagnosis, a new nodule was detected in the left testicle. Histopathological evaluation revealed a mature teratoma, clinical stage IA. Subsequently, the patient had a left orchiectomy and after 6 years of follow-up remains disease-free.

Twin- 2 was submitted to a right orchiectomy at 22 years of age, after presenting with a palpable tumor in the right testicle. Histopathological analyses revealed a pure classical seminoma (pT1NxMx) (Figure 1C-D) with no vascular or lymphatic invasion. The adjacent testicular anatomy (rete testis, epididymis, tunica albuginea, tunica vaginalis and spermatic cord) was not compromised. It was pathologically staged as $1 \mathrm{~A}$, indicated a good prognosis; therefore no adjuvant treatment was required. Fifteen months later, testicular ultrasound detected a new solid nodule in the left testicle measuring $0.5 \mathrm{~cm}$, associated with microlithiasis, diagnosed as a classic seminoma, without any other germ cell component. The patient underwent wedge resection of the tumor nodule and adjuvant radiotherapy (25.5 Gy) was administered to the remaining testis. After four years of follow-up, the patient remains diseasefree.

\section{Genome screening using array-based comparative genomic hybridization (array- CGH)}

Formalin fixed paraffin-embedded tumors, one embryonal carcinoma (Twin-1 $t$ ) and one seminoma (Twin- $2 \mathrm{t}$ ), were macro-dissected and genomic DNA extracted using a standard phenol/chloroform method. The same protocol was applied for DNA extraction from peripheral blood from the twins and their parents. The Peripheral blood samples, tumors and reference genomic DNA (Promega, G1471, male) were differentially labeled using a Genomic DNA Enzymatic Labeling Kit (Agilent Technologies, Santa Clara, CA, USA). Hybridization was performed using Agilent Human CGH 44 K Oligo Microarrays according to the manufacturer's instructions. The array images were acquired using a DNA microarray scanner with Surescan High- Resolution Technology (Agilent Technologies, Santa Clara, CA) and Scan Control (version 8.1, Agilent Technologies) software. The data were extracted and normalized using the Feature Extraction software (version 10.1.1.1, Agilent Technologies). Statistical analysis was performed using the Nexus Copy Number software (version 7.5 - Hg19, Biodiscovery Inc., El Segundo, CA, USA). The Fast Adaptive States Segmentation Technique 2 (FASST2) algorithm and Significance Testing for Aberrant Copy number (STAC) statistical methods were used to identify non-random genomic copy-number alterations [23]. According to these algorithms, DNA copy number alteration was defined as follows: exceeding the significance threshold of $1 \times 10^{-5}$; containing at least three consecutive altered probes per segment; and specified $1000 \mathrm{~kb}$ as being the maximum spacing between adjacent probes. These parameters were used to define the values for copy number gains ( $\log 2 \geq 0.2)$, high copy number gains $(\log 2 \geq 0.6)$, $\operatorname{losses}(\log 2 \leq-0.2)$ and homozygous losses $(\log 2 \leq-1.0)$.

\section{Copy number variation analyses}

The altered genomic regions observed were initially compared with the CNV described in the Database of Genomic Variants (DGV) (http://dgvbeta.tcag.ca/dgv/app/home? ref=GRCh37/hg19/, November 2013) and then with a $\mathrm{CNV}$ reference obtained from a database of the Brazilian population [24]. The CNVs were subsequently classified according to their genomic size and polymorphic frequency as follows: common (regions larger than $100 \mathrm{~kb}$ and often present in DGV frequencies greater than or equal to $1 \%$ ); rare (regions larger than $100 \mathrm{~kb}$ and often present in DGV frequencies less than or equal to $1 \%$ ); and novel (regions larger than $100 \mathrm{~kb}$ and not yet described in the DGV). This study focused only on rare or novel CNVs. Despite the majority of the CNV described in this study having a partial intersection with the common regions identified in the DGV database, the total CNV length had not yet been described in either the DGV or the Brazilian database. In addition, only genes mapped in these regions not covered by common CNVs were considered.

\section{Quantitative real-time PCR (qPCR) analysis}

The genomic DNA sequences of candidate region were obtained from the Ensembl Genome Browser website (GRCh37/hg19 Human Reference Assembly; February 2009). The reactions were performed in triplicate and followed PCR cycling conditions as previously described by [25]. Briefly, primer pair of CNTNAP3 gene (covering the same probes represented in the $4 \times 44 \mathrm{~K}$ Agilent plataform) was designed to amplify the altered regions detected by using array-CGH (Forward: TCCAGACAGATGAGCA AAACATA; Reverse: AGAAAGAAAGACAACTCTCTGC $T)$. Delta-delta $C t$ model was used to calculated the relative copy numbers [26] based on the CNTNAP3/HPRT (reference gene) ratio. This value was defined as a loss when the ratio was $<0.68$ and as a gain when the ratio was $>1.47$.

\section{Results and discussion}

There is a strong hereditary component in testicular germ cell tumors as demonstrated by twin studies $[6,7,27,28]$. Over the past 10 years, pertinent advances have been reported in MZ twin CNV studies, revealing an association with disease susceptibility, including neurological disorders (amyotrophic lateral sclerosis, Parkinson disease and Lewy body dementia) and psychiatric disorders (autism, bipolar disorder and schizophrenia) [29-32]. The present study is thought to be the first report demonstrating the novel and rare $\mathrm{CNV}$ profiles of a pair of $\mathrm{MZ}$ twins with 
different testicular germ cell tumor phenotypes. The study design was used for both the peripheral blood samples from the twins and their parents as well as the tumors (seminoma and embryonal carcinoma) from twins.

\section{Comparison between constitutional CNVs from parents and siblings}

The array-CGH profiles obtained from the genomic DNA of the peripheral blood from the father (Parent-1) and the mother (Parent-2) were compared to their sons (Twin-1b and Twin-2b). Parents and siblings shared similar patterns in terms of common CNVs. Rare or novel CNVs were not detected during these comparisons, most likely due to the low resolution of the platform. The peripheral blood samples from the MZ twins presented a discordant genotype profile, suggesting the contribution of post- zygotic events. The differences in genetic profiles of $\mathrm{MZ}$ twins has been previously characterized according to alterations involving the number or morphology of chromosomes, chromosomal mosaicism, single nucleotide polymorphisms and epigenetic modifications [33]. In this study, a panel of potentially pathogenic and novel CNVs was identified by array-CGH in each twin (Tables 1 and 2).

\section{Comparison between the genomic profiles of the blood} and tumor from Twin-1

The comparison between the genomic alterations found in the peripheral blood and tumor samples from Twin-1 revealed the presence of minimal regions of gain at $\mathrm{Xq} 28$. The Xq28 locus harbored seven genes (MAGEA2, MAGEA2B, FATE1, LAGE3, CTAG1B, CTAG1A and $C T A G 2)$, three of which are responsible for encoding the cancer-testis antigens CTAG1B, CTAG1A and CTAG2. The cancer-testis antigens (CTA) are highly expressed in normal germ line cells as well as in many cancers, where they are associated with advanced disease and a poor prognosis [34,35]. Several studies have demonstrated that CTA production in tumor cells occurs due to reactivation of the gametogenic expression program as result of genomic instability [35-37]. In the present study, gains of Xq28 CTA-cluster in embryonal carcinoma and blood samples obtained from Twin-1 were identified. This cluster was not observed for the seminomatous from Twin-2.

\section{Comparison between the genomic profile in blood and tumor from Twin-2}

The peripheral blood and tumor samples from Twin-2 shared novel CNV involving gains at Xq27.3. This CNV was not detected in embryonal carcinoma from Twin-1. Nine genes were mapped on Xq27.3, including six miRNAs (miR890, miR888, miR891A, miR891B, miR892A and $m i R 892 B$ ). miR890 and miR888 have previously been described as body fluid-specific, only detected in semen and epididymal tissue [38]. However, no association has been described for TGCT. Although these findings are interesting, further studies are required in

Table 1 Significant copy number variation (CNVs) regions detected by array-CGH

\begin{tabular}{|c|c|c|c|c|c|c|c|c|}
\hline \multirow[t]{2}{*}{ Cytoband $^{\#}$} & \multicolumn{2}{|l|}{ Samples } & \multirow[t]{2}{*}{ Start } & \multirow[t]{2}{*}{ Stop } & \multirow{2}{*}{$\begin{array}{l}\text { Length } \\
\text { (pb) }\end{array}$} & \multirow[t]{2}{*}{ Event } & \multirow[t]{2}{*}{$\mathbf{N}^{\circ}$} & \multirow[t]{2}{*}{ Gene ID } \\
\hline & Blood & Tumor & & & & & & \\
\hline \multirow[t]{2}{*}{ 9p12-p13.1 } & Twin-1b & & \multirow[t]{2}{*}{38.944 .256} & \multirow[t]{2}{*}{40.498 .819} & \multirow[t]{2}{*}{1554563} & \multirow[t]{2}{*}{ Loss } & \multirow[t]{2}{*}{7} & \multirow{2}{*}{$\begin{array}{l}\text { CNTNAP3, SPATA31A1, SPATA31A2, ZNF658B, } \\
\text { LOC653501, DQ586551 and CNTNAP3B }\end{array}$} \\
\hline & Twin-2b & & & & & & & \\
\hline \multirow[t]{2}{*}{ 10p15.3-p15.2 } & & & \multirow[t]{2}{*}{$1,056,859$} & \multirow[t]{2}{*}{$3,168,906$} & \multirow[t]{2}{*}{2112047} & \multirow[t]{2}{*}{ Loss } & \multirow[t]{2}{*}{18} & \multirow{2}{*}{$\begin{array}{l}\text { ADARB2, ADARB2-AS1, AK097474, AK127347, } \\
\text { AX748285, IDI1, IDI2, IDI2-AS1, PFKP, WDR37* }\end{array}$} \\
\hline & & Twin-2 t & & & & & & \\
\hline \multirow[t]{2}{*}{ 12p12.3-p11.1 } & & Twin-1 t & \multirow[t]{2}{*}{15.161 .204} & \multirow[t]{2}{*}{34.278 .525} & \multirow[t]{2}{*}{19117321} & \multirow[t]{2}{*}{ Gain } & \multirow[t]{2}{*}{126} & \multirow{2}{*}{$\begin{array}{l}\text { PLCZ1, CAPZA3, CASC1, KRAS, ASUN, PPFIBP1, } \\
\text { DDX11, MANSC4, KLHL42, PTHLH* }\end{array}$} \\
\hline & & Twin-2 t & & & & & & \\
\hline \multirow[t]{2}{*}{ 12p13.33- p12.3 } & & Twin-1 t & \multirow[t]{2}{*}{0} & \multirow[t]{2}{*}{14.900 .955} & \multirow[t]{2}{*}{14900955} & \multirow[t]{2}{*}{ Gain } & \multirow[t]{2}{*}{351} & \multirow{2}{*}{$\begin{array}{l}\text { ACRBP, AKAP3, CCND2, DDX47, LRP6, NANOG, YBX3, } \\
\text { CACNA1C, FGF6, FKBP4* }\end{array}$} \\
\hline & & Twin-2 t & & & & & & \\
\hline \multirow[t]{2}{*}{$13 q 21.1-q 21.2$} & & Twin-1 t & 58.321 .428 & 60.493 .818 & 2172390 & Loss & 6 & AK097816, BC032915, CR618830, DIAPH3, TDRD3 and DIAP3 \\
\hline & & Twin-2 t & & & & & & \\
\hline $15 q 11.1-q 11.2$ & & Twin-1 t & 20.335 .887 & 23.044 .681 & 2708794 & Loss & 140 & SNORD116I, SNORD115, SNORD107, SNORD64, \\
\hline & & Twin-2 t & & & & & & $N$ \\
\hline Xq27.3 & Twin-2b & Twin-2 t & 144.344 .622 & 145.204 .327 & 859.706 & Gain & 9 & $\begin{array}{l}\text { SLITRK2, TMEM257, MIR892C, MIR890, MIR888, } \\
\text { MIR892A, MIR892B, MIR891B and MIR891A }\end{array}$ \\
\hline $\mathrm{Xq} 28$ & Twin-1b & Twin-1 t & 150.522 .209 & 153.914 .671 & 3.392 .463 & Gain & 7 & $\begin{array}{l}\text { MAGEA2, MAGEA2B, FATE1, LAGE3, CTAG1B, } \\
\text { CTAG1A and CTAG2 }\end{array}$ \\
\hline
\end{tabular}


Table 2 Specific rare and novel CNVs detected in embryonal carcinoma (Twin-1t) and seminoma (Twin-2t)

\begin{tabular}{|c|c|c|c|c|c|c|c|}
\hline Tumor Sample & Cytoband & Start (pb) & Stop (pb) & Size (pb) & Event & CNV Classification $^{\mathrm{a}}$ & Genes $^{b}$ \\
\hline Twin-1 t & 16p11.2-p11.1 & 34.059 .589 & 34.847 .384 & 787796 & Gain & $\mathrm{R}$ & $\mathrm{Nl}$ \\
\hline \multirow[t]{19}{*}{ Twin-2 $\mathbf{t}$} & $1 \mathrm{p} 31.1$ & 77.762 .182 & 78.226 .565 & 464384 & Gain & N & $\mathrm{Nl}$ \\
\hline & $1 \mathrm{p} 22.1$ & 93.075 .850 & 93.586 .348 & 510499 & Gain & $N$ & $\mathrm{Nl}$ \\
\hline & $2 p 23.3$ & 27.431 .951 & 27.496 .511 & 64561 & Gain & N & EIF2B4 \\
\hline & $2 q 33.1$ & 201.865 .021 & 202.014 .428 & 149408 & Gain & $N$ & $\mathrm{Nl}$ \\
\hline & $3 q 13.13$ & 110.529 .591 & 110.874 .657 & 345067 & Loss & $\mathrm{N}$ & $\mathrm{NI}$ \\
\hline & $3 q 13.33$ & 120.713 .729 & 120.813 .244 & 99516 & Gain & N & $\mathrm{NI}$ \\
\hline & $6 \mathrm{p} 21.1$ & 42.257 .603 & 42.545 .298 & 287696 & Gain & N & GUCA1A, GUCA1B, MRPS10 and TRERF1 \\
\hline & $8 p 11.23$ & 39.003 .502 & 39.157 .973 & 154472 & Loss & N & ADAM9 and $A D A M 32$ \\
\hline & $10 q 24.1-q 24.2$ & 99.386 .286 & 99.516 .551 & 130266 & Gain & N & PIAK2A, AVPI1, MARVELD1, ZFYVE27 and SFRP5 \\
\hline & $12 q 13.3-q 14.1$ & 56.296 .387 & 56.308 .803 & 12417 & Loss & N & $\mathrm{Nl}$ \\
\hline & $12 \mathrm{q} 24.31$ & 119.381 .319 & 119.652 .493 & 271175 & Gain & N & $\mathrm{Nl}$ \\
\hline & $14 q 11.2$ & 20.550 .697 & 20.622 .417 & 71721 & Loss & N & $\mathrm{Nl}$ \\
\hline & $14 q 23.1$ & 58.887 .110 & 59.149 .379 & 262270 & Loss & N & $\mathrm{Nl}$ \\
\hline & $15 q 25.3-q 26.1$ & 86.730 .625 & 86.986 .408 & 255784 & Gain & N & $\begin{array}{l}\text { MRPL46, MRPS11, DET1, MIR1179, MIR7-2, } \\
\text { MIR3529, AEN and ISG20 }\end{array}$ \\
\hline & 17p11.2 & 19.968.313 & 20.108 .133 & 139821 & Loss & N & $\mathrm{Nl}$ \\
\hline & $17 p 13.1$ & 7.423 .749 & 7.459 .204 & 35456 & Gain & N & $\mathrm{Nl}$ \\
\hline & $19 q 13.43$ & 62.712 .083 & 62.882 .866 & 170784 & Gain & N & $\begin{array}{l}\text { ZNF773, ZNF549, ZNF550, ZNF416, ZIK1, } \\
\text { ZNF530, ZNF134, ZNF211 and ZSCAN4 }\end{array}$ \\
\hline & $20 q 11.21$ & 29.352 .138 & 29.447 .677 & 95540 & Gain & N & DEFB116, DEFB118 and DEFB119 \\
\hline & Xp22.12-p22.11 & 20.043 .034 & 21.803 .101 & 1760068 & Gain & $\mathrm{R}$ & SCARNAYL, SMPX, YYZ and MBTPS2 \\
\hline
\end{tabular}

Legend: CNV - copy number variation; Twin-1 t - embryonal carcinoma; Twin-2 t - seminoma. Rare - R; Novel - N; No identified - NI. a - CNV classification based on the Database of Genomic Variants and in the Brazilian population reference database. b- Genes mapped in regions described as rare or novel CNV.

order to confirm that the alterations involving these miRNAs are associated with risk of developing TGCT.

\section{Comparison between the peripheral blood samples from Twin-1 and Twin-2}

Although 9p12-p13.1 losses were covered by common $\mathrm{CNVs}$, the region remained included for analysis due to its presence in blood of Twin-1 and Twin-2 (Figure 2). In addition, this region harbors potential candidate genes that have been previously described in TGCT. Seven genes were mapped in this region, including two members of the SPATA31 (AEP1) subfamily (SPATA31A1 and SPATA31A2) and CNTNAP3. The SPATA31 testisspecific gene codified an integral component of membrane that has been associated to spermatogenesis and the cell differentiation process, possibly playing a role in acrosome formation $[39,40]$. CNTNAP3 gene encodes a protein associated to cell-recognition process within the nervous system [41]. Although no significant by the criteria used in our study, loss of CNTNAP3 was detected by array-CGH in both tumor samples from twins (two consecutive probes). Quantitative real-time PCR (qPCR) was performed to confirm the loss at 9p13.1-p12 involving the CNTNAP3 gene. Relative DNA copy number loss was found in both, blood and tumor (homozygous deletion) from twins (Figure 2). The controls and parental blood samples showed relative DNA copy number within the reference interval. The $\mathrm{qPCR}$ analysis confirmed the array-CGH results as well as the homozygous deletions found in tumor samples. Overall, these data suggest that the genes mapped on 9p12-13.1 have a strong potential to be involved in testicular tumor development.

\section{Panel of novel CNVs shared by seminoma and embryonial carcinoma}

The presence of rare or novel CNVs detected in seminoma and embryonal carcinoma suggests a common mechanism that contributes to tumorigenesis. Comparative analysis of novel CNVs from the embryonal carcinoma and seminoma revealed five minimal common regions, involving gain at chromosome 12 (12p12.3-p11.1 and 12p13.33p12.3), while losses were observed at 10p15.3-p15.2, 13q21.1-q21.2 and 15q11.1-q11.2 (Figure 3).

DNA copy number alterations involving 12p have been described in both seminoma and non-seminoma. Amplification of $12 p$, as observed in the tumor samples from Twin-1 and Twin2 (Additional file 1), was first described by Atkin et al. [42], and subsequently in other studies 


\section{A}

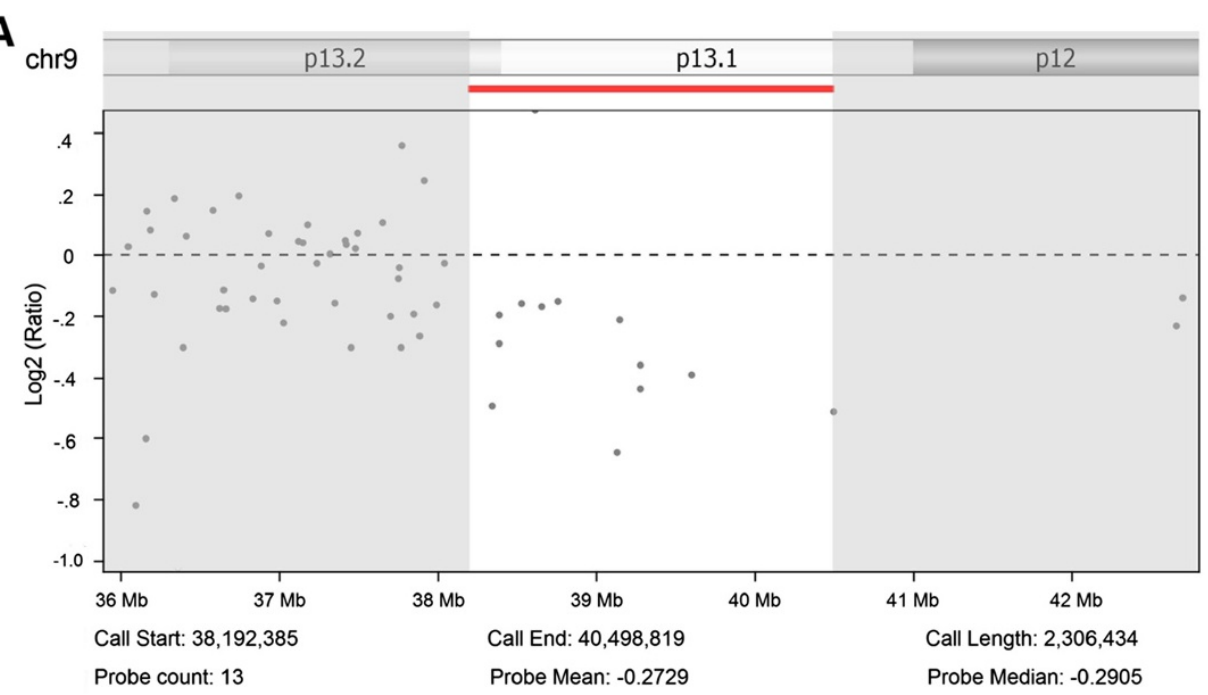

B
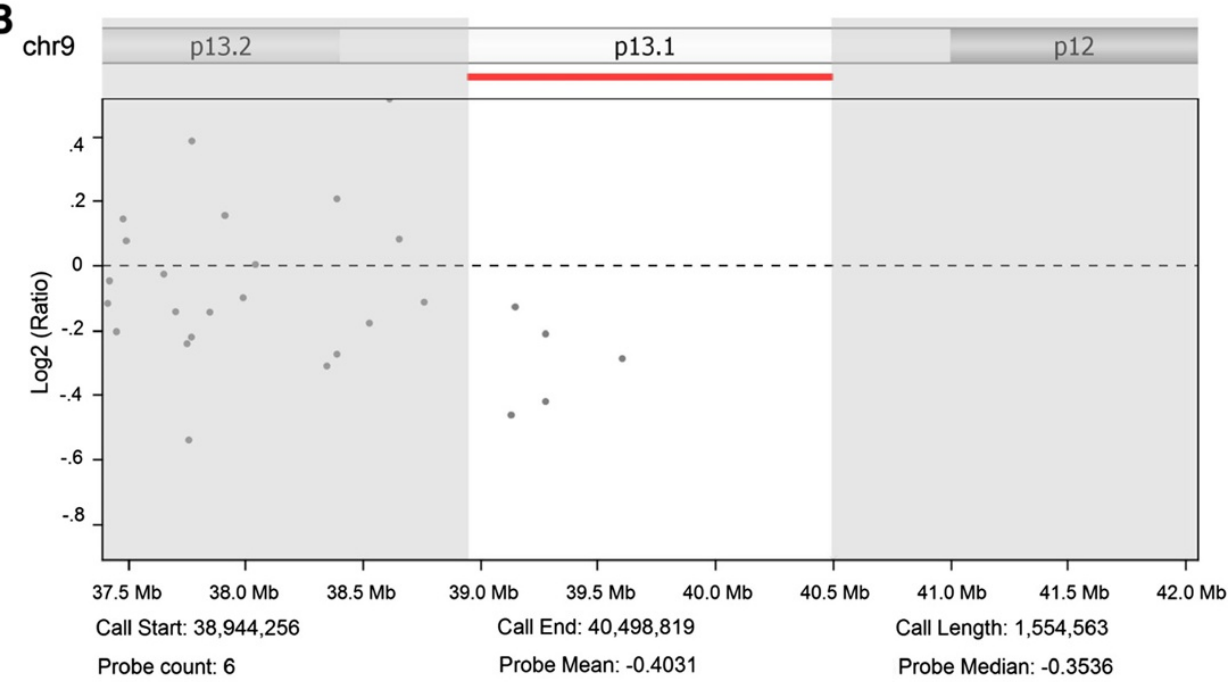

C

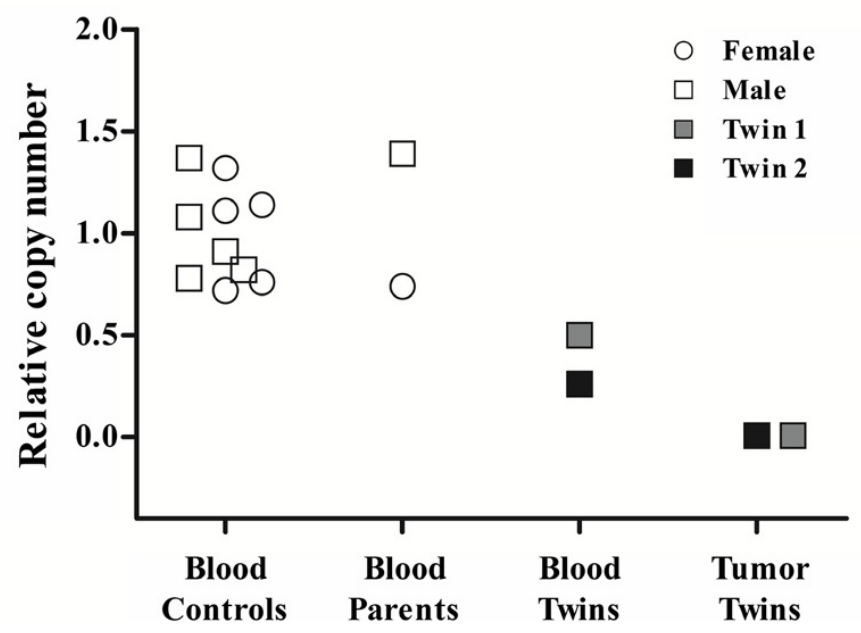

Figure $\mathbf{2}$ (See legend on next page.) 

novel CNV shared by the Twin-1 (A) and Twin-2 (B). Scatter plots with $x$-axis coordinate representing the probes positions along the genome. The low bars (red) indicate losses of genomic regions. The images were adapted from the Nexus 7.5 software. (C) Relative quantification of CNTNAP3 copy number alterations evaluated by qPCR. Normal DNA copy number (two copies) was found in the controls and parental blood. Losses were found in peripheral blood and tumor cells from twins. Image obtained from Graphpad Prism 5 (Graphpad Software Inc., La Jolla, CA).

[43-46]. Gains of $12 p$ have been detected in primordial cells responsible for determining intratubular germ cell neoplasia of the unclassified type, suggesting that possession of this alteration contributes to an invasive phenotype [47-49]. Several candidate target genes have been mapped to this region, including KRAS and CCND2, which have been associated with the malignant transformation process via the activation of pathways involved in cell proliferation $[48,50]$, or in the maintenance of germ cell pluripotency, such as DPPA3 and NANOG [46,51]. Furthermore, we identified several spermatogenesis-associated genes mapped in 12p12.3-p11.1 and 12p13.33-p12.3 including ACRBP, AKAP3, DDX47, PLCZ1, CAPZA3, ASUN and DDX11.

Eighteen genes mapped at deleted region 10p15.3-p15.2 including PFKP, ADARB2 and WDR37. In agreement with

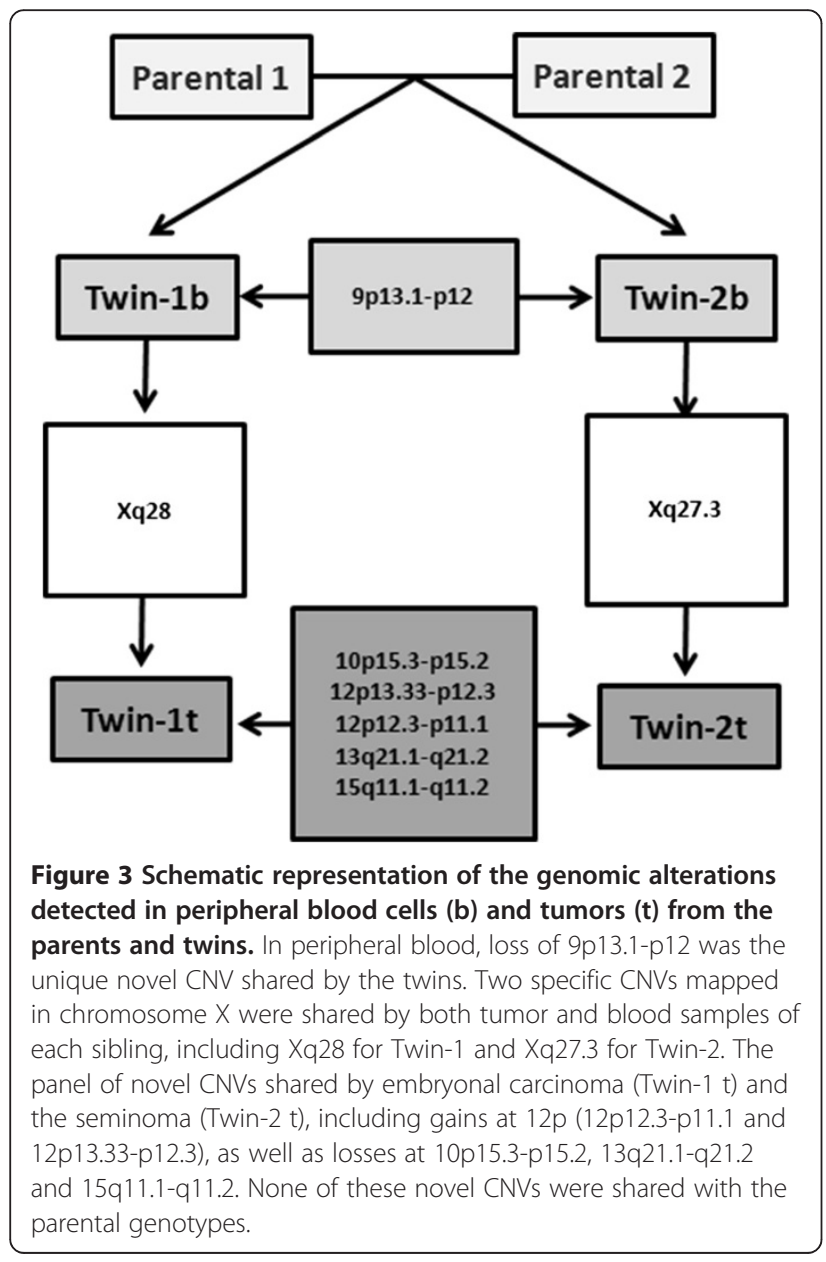

our findings, Hofer et al. [52] reported PFKP downexpression among 55 differently expressed genes in seminomas and embryonal carcinomas. A high incidence of 13q deletion has been reported in primary TGCTs $[43,44,53]$ and in non-seminomatous germ cell tumours with acquired treatment resistance [53]. In our study, it was detected losses of 13q21.1-q21.2, which harbors seven genes, including DIAPH3, TDRD3 and DIAP3. Loss of 15q11.1-q11.2 was also observed for both tumors, and involved the SNORD small nucleolar RNA (snoRNA) cluster. The SNORD116I and SNORD115 genes belong to the C/D box family of snoRNAs, and present a number of important regulatory RNA editing functions. Further studies are necessary to clarify the involvement of these small RNAs on the development of TGCT.

\section{Panel of the rare and novel tumor-specific CNVs}

The comparative analysis of seminoma and embryonal carcinoma obtained from MZ twins revealed a panel of two rare and 19 novel tumor-specific CNVs (Table 2). To our knowledge, four studies evaluated copy number variations in TGCT [54-57]. Using array-CGH, Edsgärd et al. [54] analyzed the profile of pathologic CNVs in families with germ cell tumors, including TGCT. However, only common variants were identified, including heterozygous deletion involving RLN1 (9p24.1). Subsequently the authors had evaluated common and rare CNVs in a TGCC case-control cohort, but no single locus was found to be associated with these tumors. Instead, the authors described one potential deletion of PTPN1 gene (mapped at 20q13) as rare CNVs [55]. Stadler et al. [56] described three de novo CNV events involving amplification of 7q11.22 and 12q24.1, and loss of 6 p21.2 in 3/43 familial testicular germ cell tumor trios evaluated. In a cohort of 212 cases of TGCT and 437 controls, Dalgaard et al. [57] reported a weak association for rare CNV in relation to cell migration in TGCT. These altered-locus or genes were not detected in our analysis. In agreement to the previous studies, our data suggest an association between several de novo germline structural aberrations and TGCT predisposition rather than one rare event influencing the phenotype.

\section{Conclusion}

This study constitutes the first report describing rare and novel CNVs of TGCT in monozygotic twins with divergent genomic profiles. Several CNV regions that 
harbor crucial regulatory genes were associated with TGCT pathogenesis. Loss of CNTNAP3 mapped at 9p13.1-p12 was confirmed as involved in TGCT development. Of particular importance, a pathognomonic gain of $12 p$ was confirmed exclusively in tumor samples, which was not observed in the peripheral blood of the twins or their parents. Although similar CNV profiles were shared by for both the peripheral blood and tumor samples of the twins, tumor-specific CNV loci were identified for seminoma and non- seminomatous tumors, which suggest a $\mathrm{CNV}$ origin for de novo events.

\section{Availability of supporting data}

The data set supporting the results of this article is available in the Gene Expression Omnibus (GEO) repository (www.ncbi.nlm.nih.gov/geo/). Accession number: GSE62779.

\section{Additional file}

Additional file 1: Figure S1. Hybridization profile for 12p amplification identified in tumor samples of twins. In embryonal carcinoma (A-B) and the seminoma (C), gains at $12 p$ were important novel CNV mapped at $12 p$ amplicon. The 12p12.3-p11.1 (A) and 12p13.33-p12.3 (B) were detected in Twin-1 and 12p13.33-p11.1 (C) amplicon was detected in Twin-2. Scatter plots with $\mathrm{x}$-axis coordinate representing the probes positions along the genome. The top bars (blue) indicate gains of genomic regions, whereas the lower bars (red) indicate losses of genomic regions. The images were adapted from the Nexus 7.5 software.

\section{Abbreviations}

TGCT: Testicular germ cell tumors; CNV: Copy number variation; MZ: Monozygotic twins; EC: Embryonal carcinoma.

\section{Competing interests}

The authors declare that they have no competing interests.

\section{Authors' contributions}

Elaborated and designed the experiments: SMS AL SRR. Performed the experiments: SMS. Data Analysis: SMS AFB FAM. Contributed reagents/ materials/analysis tools: FAM AL SRR. Wrote the paper: SMS IWC AL SRR. Pathological revision: IWC. All authors read and approved the final manuscript.

\section{Acknowledgments}

The authors would like to acknowledge the help of Dr Luciane Regina Cavalli for critically reading this manuscript, Dr Mateus de Camargo Barros and Graziela Spilborgs for their support in qPCR experiments.

\section{Funding}

This work was supported by the FAPESP and CNPq.

\begin{abstract}
Author details
${ }^{1}$ Neogene Laboratory, CIPE, A. C. Camargo Cancer Center, São Paulo, Brazil. ${ }^{2}$ Department of Pathology, A.C. Camargo Cancer Center, São Paulo, Brazil. ${ }^{3}$ Institute of Mathematics and Statistics, Inter-Institutional Program on Bioinformatics, USP, São Paulo, Brazil. ${ }^{4}$ Nucleus of Sarcoma, Department of Pelvic Surgery, A.C. Camargo Cancer Center, São Paulo, Brazil. ${ }^{5}$ Department of Urology, Faculty of Medicine, UNESP, Botucatu, São Paulo, Brazil.
\end{abstract}

Received: 30 April 2014 Accepted: 4 November 2014

Published online: 26 November 2014

\section{References}

1. Walsh TJ, Grady RW, Porter MP, Lin DW, Weiss NS: Incidence of testicular germ cell cancers in U.S. children: SEER program experience 1973 to 2000. Urology 2006, 68:402-405. discussion 405.

2. Chieffi P, Chieffi S: Molecular biomarkers as potential targets for therapeutic strategies in human testicular germ cell tumors: an overview. J Cell Physiol 2013, 228:1641-1646.

3. Ulbright TM: Germ cell neoplasms of the testis. Am J Surg Pathol 1993, 17:1075-1091.

4. Viatori M: Testicular cancer. Semin Oncol Nurs 2012, 28:180-189.

5. Mohamed GH, Gelfond JA, Nicolas MM, Brand TC, Sarvis JA, Leach RJ, JohnsonPais TL: Genomic characterization of testis cancer: association of alterations with outcome of clinical stage 1 mixed germ cell nonseminomatous germ cell tumor of the testis. Urology 2012, 80:e481-e485. 485.

6. Hemminki K, Li X: Familial risk in testicular cancer as a clue to a heritable and environmental aetiology. Br J Cancer 2004, 90:1765-1770.

7. Neale RE, Carrière P, Murphy MF, Baade PD: Testicular cancer in twins: a meta-analysis. Br J Cancer 2008, 98:171-173.

8. Dieckmann KP, Endsin G, Pichlmeier U: How valid is the prenatal estrogen excess hypothesis of testicular germ cell cancer? A case control study on hormone-related factors. Eur Urol 2001, 40:677-683. discussion 684.

9. Richiardi L, Akre O, Lambe M, Granath F, Montgomery SM, Ekbom A: Birth order, sibship size, and risk for germ-cell testicular cancer. Epidemiology 2004, 15:323-329.

10. Raman JD, Nobert CF, Goldstein M: Increased incidence of testicular cancer in men presenting with infertility and abnormal semen analysis. J Urol 2005, 174:1819-1822. discussion 1822

11. Walsh TJ, Croughan MS, Schembri M, Chan JM, Turek PJ: Increased risk of testicular germ cell cancer among infertile men. Arch Intern Med 2009, 169:351-356.

12. Lutke Holzik MF, Sijmons RH, Sleijfer DT, Sonneveld DJ, Hoekstra-Weebers JE, van Echten-Arends J, Hoekstra HJ: Syndromic aspects of testicular carcinoma. Cancer 2003, 97:984-992.

13. Crockford GP, Linger R, Hockley S, Dudakia D, Johnson L, Huddart R, Tucker K, Friedlander M, Phillips KA, Hogg D, Jewett MA, Lohynska R, Daugaard G, Richard S, Chompret A, Bonaïti-Pellié C, Heidenreich A, Albers P, Olah E, Geczi L, Bodrogi I, Ormiston WJ, Daly PA, Guilford P, Fosså SD, Heimdal K, Tjulandin SA, Liubchenko L, Stoll H, Weber W, et al: Genome-wide linkage screen for testicular germ cell tumour susceptibility loci. Hum Mol Genet 2006, 15:443-451.

14. Nathanson KL, Kanetsky PA, Hawes R, Vaughn DJ, Letrero R, Tucker K, Friedlander M, Phillips KA, Hogg D, Jewett MA, Lohynska R, Daugaard G, Richard S, Chompret A, Bonaïti-Pellié C, Heidenreich A, Olah E, Geczi L, Bodrogi I, Ormiston WJ, Daly PA, Oosterhuis JW, Gillis AJ, Looijenga LH, Guilford P, Fosså SD, Heimdal K, Tjulandin SA, Liubchenko L, Stoll H, et al: The $Y$ deletion $\mathrm{gr} / \mathrm{gr}$ and susceptibility to testicular germ cell tumor. Am J Hum Genet 2005, 77:1034-1043.

15. Tsuchiya N, Mishina M, Narita S, Kumazawa T, Inoue T, Horikawa Y, Kakinuma H, Yuasa T, Matsuura S, Satoh S, Ogawa O, Habuchi T: Association of XRCC1 gene polymorphisms with the susceptibility and chromosomal aberration of testicular germ cell tumors. Int J Oncol 2006, 28:1217-1223.

16. Houldsworth J, Korkola JE, Bosl GJ, Chaganti RS: Biology and genetics of adult male germ cell tumors. J Clin Oncol 2006, 24:5512-5518.

17. Xu WH, Zhang C, Zhao WM, Li CM, Xiu YC, Ni SB, Ren MH, Sun DJ: Mutational analysis of proto-oncogene $\mathrm{Dbl}$ on Xq27 in testicular germ cell tumors reveals a rare SNP in a patient with bilateral undescended testis. World J Urol 2009, 27:811-815.

18. Kanetsky PA, Mitra N, Vardhanabhuti S, Li M, Vaughn DJ, Letrero R, Ciosek SL, Doody DR, Smith LM, Weaver J, Albano A, Chen C, Starr JR, Rader DJ, Godwin AK, Reilly MP, Hakonarson H, Schwartz SM, Nathanson KL: Common variation in KITLG and at 5 q31.3 predisposes to testicular germ cell cancer. Nat Genet 2009, 41:811-815.

19. Rapley EA, Turnbull C, Al Olama AA, Dermitzakis ET, Linger R, Huddart RA, Renwick A, Hughes D, Hines S, Seal S, Morrison J, Nsengimana J, Deloukas P, Testicular Cancer Collaboration UK, Rahman N, Bishop DT, Easton DF, Stratton MR: A genome-wide association study of testicular germ cell tumor. Nat Genet 2009, 41:807-810.

20. Chung CC, Kanetsky PA, Wang Z, Hildebrandt MA, Koster R, Skotheim RI, Kratz CP, Turnbull C, Cortessis VK, Bakken AC, Bishop DT, Cook MB, Erickson RL, Fosså SD, Jacobs KB, Korde LA, Kraggerud SM, Lothe RA, Loud JT, Rahman N, Skinner EC, Thomas DC, Wu X, Yeager M, Schumacher FR, Greene MH, Schwartz SM, 
McGlynn KA, Chanock SJ, Nathanson KL: Meta-analysis identifies four new loci associated with testicular germ cell tumor. Nat Genet 2013, 45:680-685.

21. Ruark E, Seal S, McDonald H, Zhang F, Elliot A, Lau K, Perdeaux E, Rapley E, Eeles R, Peto J, Kote-Jarai Z, Muir K, Nsengimana J, Shipley J: Identification of nine new susceptibility loci for testicular cancer, including variants near DAZL and PRDM14. Nat Genet 2013, 45:686-689.

22. Turnbull C, Rahman N: Genome-wide association studies provide new insights into the genetic basis of testicular germ-cell tumour. Int J Androl 2011, 34:e86-e96. discussion e96-87.

23. Diskin SJ, Eck T, Greshock J, Mosse YP, Naylor T, Stoeckert CJ, Weber BL, Maris JM, Grant GR: STAC: A method for testing the significance of DNA copy number aberrations across multiple array-CGH experiments. Genome Res 2006, 16:1149-1158.

24. Krepischi AC, Pearson PL, Rosenberg C: Germline copy number variations and cancer predisposition. Future Oncol 2012, 8:441-450

25. Silveira SM, Villacis RAR, Marchi FA, Barros-Filho MC, Drigo AS, Scapulatempo C, Lopes A, Cunha IW, Rogatto SR: Genomic signatures predict poor outcome in Undifferentiated Pleomorphic Sarcomas and Leiomyosarcomas. PLoS One 2013, 8:e67643.

26. Livak KJ, Schmittgen TD: Analysis of relative gene expression data using real-time quantitative PCR and the 2(-Delta Delta C(T)) Method. Methods 2001, 25:402-408.

27. Swerdlow AJ, De Stavola BL, Swanwick MA, Maconochie NE: Risks of breast and testicular cancers in young adult twins in England and Wales: evidence on prenatal and genetic aetiology. Lancet 1997, 350:1723-1728.

28. Lichtenstein P, Holm NV, Verkasalo PK, Iliadou A, Kaprio J, Koskenvuo M, Pukkala E, Skytthe A, Hemminki K: Environmental and heritable factors in the causation of cancer-analyses of cohorts of twins from Sweden, Denmark, and Finland. N Engl J Med 2000, 343:78-85.

29. Glessner JT, Hakonarson H: Common variants in polygenic schizophrenia Genome Biol 2009, 10:236.

30. Pamphlett R, Morahan JM: Copy number imbalances in blood and hair in monozygotic twins discordant for amyotrophic lateral sclerosis. J Clin Neurosci 2011, 18:1231-1234.

31. Ehli EA, Abdellaoui A, Hu Y, Hottenga JJ, Kattenberg M, van Beijsterveldt T, Bartels M, Althoff RR, Xiao X, Scheet P, de Geus EJ, Hudziak JJ, Boomsma DI, Davies GE: De novo and inherited CNVs in MZ twin pairs selected for discordance and concordance on Attention Problems. Eur J Hum Genet 2012, 20:1037-1043.

32. Bloom R, Kähler AK, Collins AL, Chen G, Cannon TD, Hultman C, Sullivan PF: Comprehensive analysis of copy number variation in monozygotic twins discordant for bipolar disorder or schizophrenia. Schizophr Res 2013, 146:289-290.

33. Gringras $P$, Chen $W$ : Mechanisms for differences in monozygous twins. Early Hum Dev 2001, 64:105-117.

34. Scanlan MJ, Simpson AJ, Old LJ: The cancer/testis genes: review, standardization, and commentary. Cancer Immun 2004, 4:1.

35. Simpson AJ, Caballero OL, Jungbluth A, Chen YT, Old L: Cancer/testis antigens, gametogenesis and cancer. Nat Rev Cancer 2005, 5:615-625.

36. Whitehurst AW: Cause and consequence of cancer/testis antigen activation in cancer. Annu Rev Pharmacol Toxicol 2014, 54:251-272.

37. Kulkarni P, Shiraishi T, Rajagopalan K, Kim R, Mooney SM, Getzenberg RH: Cancer/ testis antigens and urological malignancies. Nat Rev Urol 2012, 9:386-396.

38. Zubakov D, Boersma AW, Choi Y, van Kuijk PF, Wiemer EA, Kayser M: MicroRNA markers for forensic body fluid identification obtained from microarray screening and quantitative RT-PCR confirmation. Int I Legal Med 2010, 124:217-226

39. Luk JM, Lee NP, Shum CK, Lam BY, Siu AF, Che CM, Tam PC, Cheung AN, Yang ZM, Lin YN, Matzuk MM, Lee KF, Yeung WS: Acrosome-specific gene AEP1: identification, characterization and roles in spermatogenesis. J Cell Physiol 2006, 209:755-766.

40. Zuo Y, Gao J, Yeung WS, Lee KF: The testis-specific VAD1.3/AEP1 interacts with $\beta$-actin and syntaxin 1 and directs peri-nuclear/Golgi expression with bipartite nucleus localization (BNL) sequence. Biochem Biophys Res Commun 2010, 401:275-280.

41. Spiegel I, Salomon D, Erne B, Schaeren-Wiemers N, Peles E: Caspr3 and caspr4, two novel members of the caspr family are expressed in the nervous system and interact with PDZ domains. Mol Cell Neurosci 2002, 20:283-297.

42. Atkin NB, Baker MC: Specific chromosome change, $i(12 p)$, in testicular tumours? Lancet 1982, 2:1349.

43. Mostert MM, van de Pol M, Olde Weghuis D, Suijkerbuijk RF, Geurts van Kessel A, van Echten J, Oosterhuis JW, Looijenga LH: Comparative genomic hybridization of germ cell tumors of the adult testis: confirmation of karyotypic findings and identification of a 12p-amplicon. Cancer Genet Cytogenet 1996, 89:146-152.

44. Summersgill B, Goker H, Weber-Hall S, Huddart R, Horwich A, Shipley J: Molecular cytogenetic analysis of adult testicular germ cell tumours andidentification of regions of consensus copy number change. Br J Cancer 1998, 77:305-313.

45. Mclntyre A, Summersgill B, Jafer O, Rodriguez S, Zafarana G, Oosterhuis JW, Gillis AJ, Looijenga L, Cooper C, Huddart R, Clark J, Shipley J: Defining minimum genomic regions of imbalance involved in testicular germ cell tumors of adolescents and adults through genome wide microarray analysis of cDNA clones. Oncogene 2004, 23:9142-9147.

46. Skotheim Rl, Autio R, Lind GE, Kraggerud SM, Andrews PW, Monni O, Kallioniemi O, Lothe RA: Novel genomic aberrations in testicular germ cell tumors by array-CGH, and associated gene expression changes. Cell Oncol 2006, 28:315-326.

47. Summersgill BM, Jafer O, Wang R, Goker H, Niculescu-Duvaz I, Huddart R, Shipley J: Definition of chromosome aberrations in testicular germ cell tumor cell lines by 24-color karyotyping and complementary molecular cytogenetic analyses. Cancer Genet Cytogenet 2001, 128:120-129.

48. Rodriguez S, Jafer O, Goker H, Summersgill BM, Zafarana G, Gillis AJ, Van Gurp RJ, Oosterhuis JW, Lu YJ, Huddart R, Cooper CS, Clark J, Looijenga LH, Shipley JM: Expression profile of genes from $12 p$ in testicular germ cell tumors of adolescents and adults associated with $\mathrm{i}(12 \mathrm{p})$ and amplification at 12p11.2-p12.1. Oncogene 2003, 22:1880-1891.

49. Zafarana G, Grygalewicz B, Gillis AJ, Vissers LE, van de Vliet W, van Gurp RJ, Stoop H, Debiec-Rychter M, Oosterhuis JW, van Kessel AG, Schoenmakers EF, Looijenga LH, Veltman JA: 12p-amplicon structure analysis in testicular germ cell tumors of adolescents and adults by array CGH. Oncogene 2003, 22:7695-7701.

50. Skotheim RI, Monni O, Mousses S, Fosså SD, Kallioniemi OP, Lothe RA, Kallioniemi A: New insights into testicular germ cell tumorigenesis from gene expression profiling. Cancer Res 2002, 62:2359-2364.

51. Gillis AJ, Stoop H, Biermann K, van Gurp RJ, Swartzman E, Cribbes S, Ferlinz A, Shannon M, Oosterhuis JW, Looijenga LH: Expression and interdependencies of pluripotency factors LIN28, OCT3/4, NANOG and SOX2 in human testicular germ cells and tumours of the testis. Int J Androl 2011, 34:e160-e174

52. Hofer MD, Browne TJ, He L, Skotheim RI, Lothe RA, Rubin MA: Identification of two molecular groups of seminomas by using expression and tissue microarrays. Clin Cancer Res 2005, 11:5722-5729.

53. Hiorns LR, Seckl MJ, Paradinas F, Sharp SY, Skelton LA, Brunstrom G, Newlands ES, Kelland LR, Leyland-Jones B: A molecular cytogenetic approach to studying platinum resistance. J Inorg Biochem 1999, 77:95-104.

54. Edsgärd D, Scheel M, Hansen NT, Ralfkiaer U, Jensen TS, Skakkebaek NE, Brunak S, Gupta R, Rajpert-De Meyts E, Ottesen AM: Heterozygous deletion at the RLN1 locus in a family with testicular germ cell cancer identified by integrating copy number variation data with phenome and interactome information. Int J Androl 2011, 34:e122-e132.

55. Edsgärd D, Dalgaard MD, Weinhold N, Wesolowska-Andersen A, Rajpert-De Meyts E, Ottesen AM, Juul A, Skakkebæk NE, Skøt Jensen T, Gupta R, Leffers $H$, Brunak S: Genome-wide assessment of the association of rare and common copy number variations to testicular germ cell cancer. Front Endocrinol (Lausanne) 2013, 29:4:2

56. Stadler ZK, Esposito D, Shah S, Vijai J, Yamrom B, Levy D, Lee YH, Kendall Leotta A, Ronemus M, Hansen N, Sarrel K, Rau-Murthy R, Schrader K, Kauff N, Klein RJ, Lipkin SM, Murali R, Robson M, Sheinfeld J, Feldman D, Bosl G, Norton L, Wigler M, Offit K: Rare de novo germline copy-number variation in testicular cancer. Am J Hum Genet 2012, 91:379-383.

57. Dalgaard MD, Weinhold N, Edsgärd D, Silver JD, Pers TH, Nielsen JE, Jørgensen N, Juul A, Gerds TA, Giwercman A, Giwercman YL, CohnCedermark G, Virtanen HE, Toppari J, Daugaard G, Jensen TS, Brunak S, Rajpert-De Meyts E, Skakkebæk NE, Leffers H, Gupta R: A genome-wide association study of men with symptoms of testicular dysgenesis syndrome and its network biology interpretation. J Med Genet 2012, 49:58-65.

\section{doi:10.1186/s13023-014-0181-x}

Cite this article as: Silveira et al:: Genomic screening of testicular germ cell tumors from monozygotic twins. Orphanet Journal of Rare Diseases 2014 9:181. 